cubation for the growth of bacteria was $48 \mathrm{~h}$; (4) that with 4 and $5 \mathrm{mg} / \mathrm{l}$. cobalt, there was a decrease in the growth and the vitamin content of the organism; (5) that there was no alkali stable $B_{12}$ activity in the culture. Table 1. INFLUENCE OF COBALT ON THE GROWTH OF $P$. freudenreichii Turbidity (Klett

Treatment (cobalt
mg/l.)
0 (Control)
1
2
3
4
5

*The values for the suspensions at the end of $48 \mathrm{~h}$ did not appreciably differ from those obtained at the end of $72 \mathrm{~h}$.

Table 2. Influknce of Cobalt on Vitamin $B_{12}$ Aotivity on P. freudenreichii AFTER INCUBATION AT $30^{\circ} \mathrm{C}$ FOR $48 \mathrm{~h}$

Treatment (cobalt, $\mathrm{mg} / \mathrm{l}$ ) Dry weight (mg) Vitamin $\mathbf{B}_{1 \mathrm{~s}} *(\mu \mathrm{g} / \mathrm{g}$

$4 \mathrm{~h} \quad 48 \mathrm{~h}$

$40-49$

$\begin{array}{ll}62 & 138 \\ 68 & 168\end{array}$

$\begin{array}{lll}0 & 40 \\ 8 & 38\end{array}$

$\begin{array}{ccr}0 \text { (Control) } & 0 \cdot 0980 & 600 \\ 1 & 0 \cdot 1080 & 1,000 \\ 2 & 0 \cdot 1460 & 1,400 \\ 3 & 0 \cdot 1523 & 1,800 \\ 4 & 0 \cdot 0128 & 800 \\ 5 & 0 \cdot 0116 & 596 \\ \text { * There was no alkali stable vitamin } & \mathrm{B}_{12} \text { activity. }\end{array}$

These results thus indicate the possibility of considerably increasing the vitamin $B_{12}$ content of the cells of $P$. freudenreichii, by having the optimum cobalt con. centration in the medium.

S. SATHYANARAyana RaO
D. R. WAsHINGTON
Environmental Engineering Division,$$
\text { Troy, }
$$

New York.

' Leviton, A., and Hargrove, B. S., Indus. Eng. Chem., 44, 2651 (1952).

"Riley, P. B., Jackson, P. W., Ross, D., and Savage, P. A., Continuous Culture of Microorganisms, S.C.I. Monograph No. 12, 127 (1961).

"Janicki, J., and Pawelkeiwiez, J., Acta Biochem. Polon., 1, 307 (1954).

${ }^{4}$ Pawelkeiwiez, J., Acta Biochem. Polon., 1, 313 (1954).

- Perlman, D., and Barrett, J. M., Canad. J. Microbiol., 4, 9 (1958).

${ }^{6}$ Neujahr, H. Y., Kurz, W. G., and Ross-Ricci, G., Arkiv. Kemi., 15, 363 (1960).

"Sathyanarayana kao, S., and Srinath, E. G., J. Sci. Indust. Res., 20c, 261 (1961).

s Skeggs, H. r., Nipple, H. M., Valentik, K. A., Huff, J. W., and Wright,

L. 1., J. Biol. Chem., 184, 211 (1950).

\section{Agar Electrophoresis of Colicines with an Alcaligenes faecalis Indicator Strain}

Strains of Alcaligenes faecalis (unpublished observations) previously used ${ }^{1}$ are not inhibited by colicines $A-K$ and $V$ apart from $A$. faecalis strain N.C.T.C. 8769, which is inhibited by colicinogenic strains $C A 38, C A 23, C A 42$, $C A 46, C A 57, C A 58, C A 62$ and $P$ 14, kindly supplied by Prof. P. Fredericq.

The agar electrophoresis method used is a modification of Chapple's ${ }^{2}$ procedure and will be described at a later date. The broth and agar used were the $\operatorname{Pr}_{3}$ media of Ben-Gurion and Hertman ${ }^{3}$ with the sodium chloride and sodium phosphate content reduced by half. The soft top layer used contained $0 \cdot 7$ per cent agar. Strain $C A 38$ which produces colicines $E$ and $I$ was stabbed in the centre of a 12-in. square agar plate and incubated for $36 \mathrm{~h}$ at $37^{\circ} \mathrm{C}$. The growth was then killed with chloroform vapour and a potential of $50 \mathrm{~V}$ was applied across the agar for $16 \mathrm{~h}$. The current taken was approximately 130 m.amp. Electrophoresis was conducted in a refrigerator to aid cooling. The plate was then layered with soft agar containing $A$. faecalis strain N.C.T.C. 8769 as indicator and incubated overnight. An area of inhibition was found in the region of the anode quite unlike published photographs of electrophoresis of colicines. This result was perfectly reproducible. A composite experiment was arranged on another plate using indicators N.C.T.C. 8769 and coli $\varphi$.
The latter is sensitive to all known colicines, including $E_{1}$, $E_{2}$ and $I$. Results shown in Fig. 1 reveal an inhibitory faction produced by $C A 38$ for N.C.T.C. 8769 distinct from the other colicines registered by coli $\varphi$. This inhibitory area was $2.5 \mathrm{~cm}$ in diameter and clear with a shelving edge. Stab inocula of this clear area always produced growth of the indicator strain still sensitive to further inhibition. This inhibitory fraction has not been obtained in solution. It is inactivated by trypsin and also by heating at $75^{\circ} \mathrm{C}$ for $30 \mathrm{~min}$.

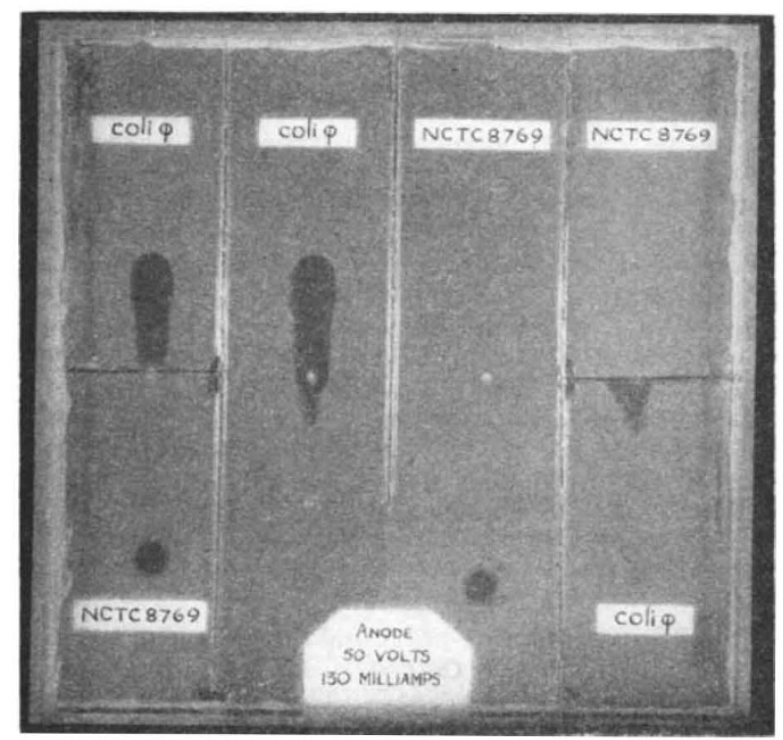

Fig. 1, Strain CA 38 was stabbed at four sites in the agar in the middle of an electrophoresis plate and grown for $36 \mathrm{~h}$. The growths were then killed with chloroform vapour and a potential of $50 \mathrm{~V}$ applied across the plate for $16 \mathrm{~h}$ in a refrigerator. The plate was divided into 6 compartments with glass strips and again sterilized. The compartments were then covered with soft agar containing the indicator strains shown and incubated overnight

Work on the other colicinogenic strains mentioned has shown that they also produce further distinct inhibitory agents the properties of which will be presented in a further communication.

I. J. MARÉ

J. N. Comtzee

Department of Microbiology,

H. C. DE KLERK

University of Pretoria.

${ }^{1}$ Maré, I. J., and Coetzee, J. N., Nature, 197, 1322 (1963).

${ }^{2}$ Chapple, P. J., J. Clin. Path., 15, 484 (1962).

${ }^{3}$ Ben-Gurion, R., and Hertman, I., J. Gen. Microbiol., 19, 289 (1958).

\section{VIROLOGY}

\section{Spread of Groundnut Rosette Virus by Aphis craccivora (Koch)}

Iт has been known for many years ${ }^{1}$ that close spacing of groundnuts, Arachis hypogaea L., reduces the incidence of groundnut rosette in a crop. Storey and Ryland 2 pointed out that there was a reduction in the number of rosette virus-infected plants per unit area of land, as well as the reduction in percentage infection that would be expected with larger plant populations associated with close spacing ${ }^{3}$. Analyses of experiments on groundnut spacing ${ }^{4}$ have confirmed this result, but in a few experiments there were no significant differences in the numbers of infected plants per unit area at harvest 5,6 .

At one time it was suggested that the reduction in infections per unit area might be due to the moister ecoclimate of closer-spaced plants favouring the spread of entomophagous fungi among the colonizing Aphis craccivora (the vector of rosette virus) and thereby limiting 